\title{
An archaeological experiment and new knowledge about the chipped stone industry from the Vinča culture
}

\author{
Vera Bogosavljević Petrović \\ National Museum in Belgrade. Trg Republike 1a, 11000 Belgrade, Serbia. \\ Email: v.bogosavljevic@narodnimuzej.rs
}

\begin{abstract}
:
In order to examine the hypothesis of our knowledge on the Vinča chipped stone industry which was spreading on the territory of Serbia during the Late Neolithic until the Chalcolithic (the end of the $6^{\text {th }}$ and the beginning of the $5^{\text {th }}$ millennia BCE) and the previously noticed changes within it, we started from the question about the process of chipped stone tool production and the life cycle of artefacts. A series of preparatory activities in making replicas of flint sickles and the realization of a harvesting process contributed to gaining better knowledge on sequences of stone production technology, from the supply strategy to the production and utilization of artefacts. The main goal of the experiment was to obtain authentic traces of use on the working edges and creation of the first visual comparative database with examples from the region.

Preliminary results essentially influenced our determination of the methods applied for reduction sequences during the Vinča culture. A significant result was achieved with the first quantifications of raw materials for making tools, such as a sickle and needs during one season, as well as with the precise definition of areas of sown land necessary for maintenance of an average Vinča family.
\end{abstract}

Keywords: experimentation; sickle gloss; micro-wear analysis; Late Neolithic; Early Chalcolithic; Vinča culture; Central Balkans

\section{Introduction}

The period from the end of the $6^{\text {th }}$ and the beginning of the $5^{\text {th }}$ millennia BCE belonged to the bearers of the Vinča culture in the territory of modern Serbia (Figure 1). Its influence was felt far beyond its boundaries. Besides a large number of established practices, from the emergence of tell settlements and flat supersites to hamlets in mountain scenery (Borić 2015), from the explosion of stone artefact production to metallurgical installations, this culture is important, above all, for studying formative processes in the emergence of new societies and relations among them (Porčić 2012; Tripković 2013; Bogosavljević Petrović 2015: 407-520). In absolute dates, this period has a time span of ca. 5350-4650 cal. BCE (Borić 2009: fig. 47).

Pressure technique and indirect punch technique with soft hammers were probably dominant working processes in the Vinča culture with the purpose to produce standardized blank blades according to their forms and dimensions. Although the knowledge of extraction

Published by the School of History, Classics and Archaeology, University of Edinburgh ISSN: 2055-0472. URL: http://journals.ed.ac.uk/lithicstudies/

This work is licensed under a Creative Commons Attribution 2.5 UK: Scotland License. 
of suitable copper ores, smelting and making artefacts were already at a developed level, their production was not a dominant source of providing tools and weapons for everyday life (Hansen 2013: 140-160). The most important changes within the Vinča culture in the central Balkans were connected with the processing of metal ores with a simultaneous enormous increase in lithic production (Bogosavljević Petrović 2015: 497-500). In that sense, there arises a question of share and importance of production of chipped stone tools in the period of Early Chalcolithic in the Balkans.

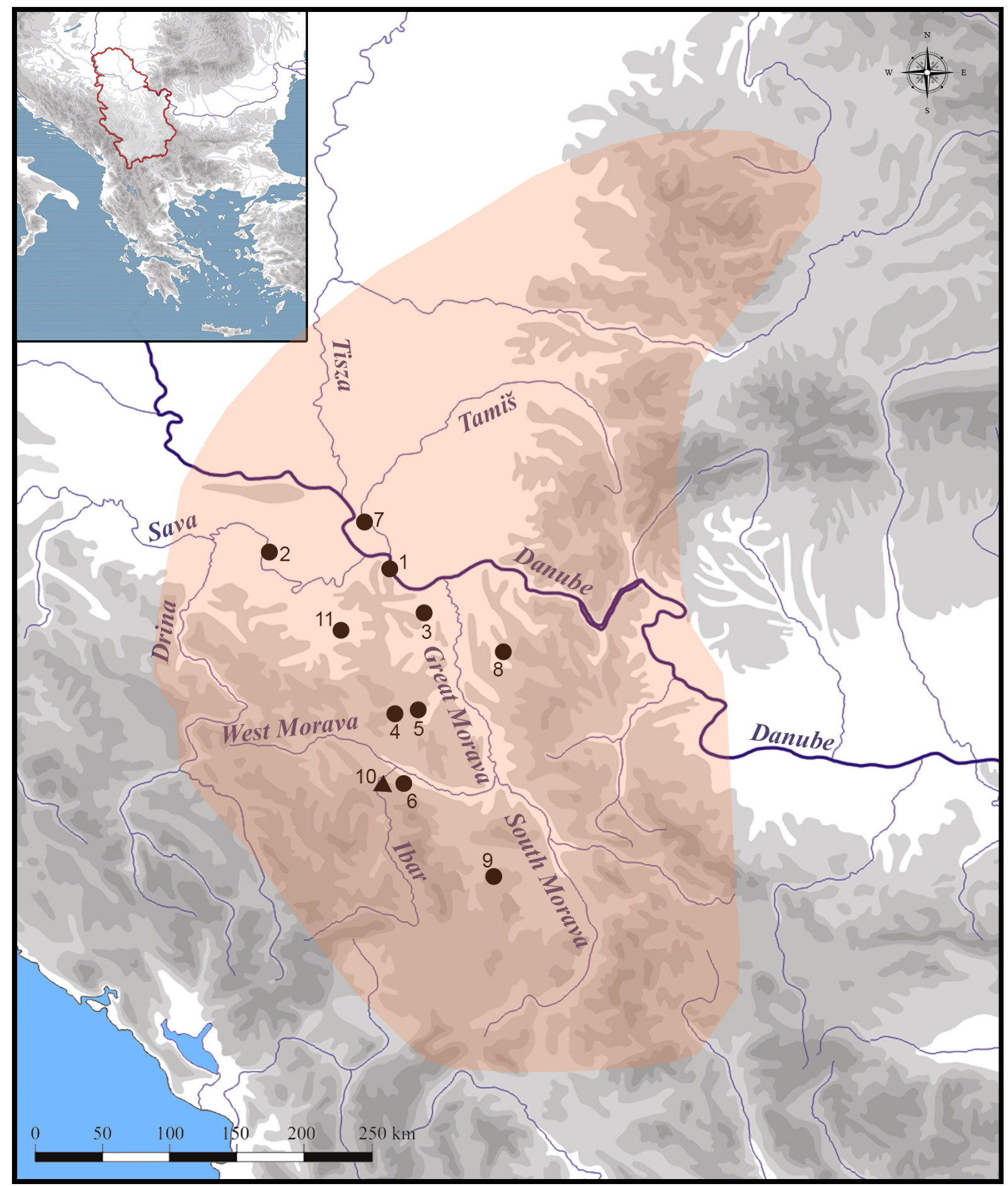

Figure 1. Approximate territory of the Vinča culture. Sites mentioned in the text: 1 Vinča-Belo Brdo, 2 Gomolava, 3 Selevac, 4 Grivac, 5 Divostin 6 Divlje polje, 7 Opovo, 8 Belovode, 9 Pločnik. 10 Lojanik mine, 11 Crkvine-Mali Borak. 
Regardless of the respectable data fund, the question we made to ourselves was very simple: how much do we really know the world of Vinča people from inside? What do our results of statistical and petroarchaeological analyses, different concepts in the supply and technology of production of chipped stone tools in the northern and southern provinces of the culture mean? A rich series of information about the lithic technological organization had already been collected at one place, the methods of providing raw materials had been the subject of petroarchaeological studies for years, several models of the flow of raw materials had been established (Bogosavljević Petrović 2015: fig. 115). But, that was a view from the outside.

A step closer to a more reliable picture is provided by analyses of traces of use on chipped stone artefacts, archaeological experiments and ethnoarchaeological research. The first corpus of studies had already existed in Serbian literature in the form of published results of functional analyses of assemblages from several Late Neolithic sites (Figure 1, site numbers 1-3, 5, and 7). They refer to international projects realized during the eighth and ninth decades of the last century (Bogosavljević \& Marković 2012). The main weakness of those investigations was publishing results without illustrated examples, sometimes only with schematized representations. It is the case with assemblages from Divostin (Tringham et al. 1988: 210-221), Vinča-Belo Brdo (Voytek 1984:54-58), Selevac (Voytek 1990: 473-481), Gomolava (Kaczanowska \& Kozłowski 1986: 115-119) and Opovo (Tringham et al. 1985; Tringham et al. 1992). It was not possible to compare the results of investigations of the assemblage from Vinča-Belo Brdo from the last series of excavations (1998-2007) with the already existing data. The obstruction was overcome by setting basic criteria for micro-wear analysis. In addition to preparation of a reference photo collection of microscopically recorded traces on chipped stone tools, it implied devising special archaeological experiments, making replicas of typologically different tools, simulation of use and recording traces of use as a complementary data source.

\section{Material and Methods}

In the assemblage of 4585 specimens from Vinča-Belo Brdo site (research 1998-2007), 1935 (43\%) artefacts with traces of physical-chemical changes were macroscopically identified. The application of microscopic analyses started in 2005 in the Laboratory of Chemistry of the National Museum in Belgrade (LCNMB). 1935 pieces of potentially used specimens with various damages were taken for analysis. Besides a series of problem questions, from the process of cutting on different materials up to the use of microperforators, this heterogeneous assemblage of tools and knapping products provided a selection of 50 medial blades with the traces of rounding, micropolish and polished zones as the first group of artefacts suitable for formation of a comparative collection of traces of grain cutting. The artefacts were made using various raw materials, from amorphous chert, white chert, opal and volcaniclastic rocks.

The specimens were observed by means of the binocular magnifying glass type OLYMPUS SZ 61 in reflected light with the possibility of magnification from 10 to 60 times, by means of the metallographic microscope OLYMPUS BX51M, in reflected light, in the dark field, with the possibility of magnification from 50 to 200 times (LCNMB) and the electron microscope type JEOL JSM-6610LV (The Faculty of Mining and Geology in Belgrade - RGFB). By using the photo basis from the first 500 microphotos of traces of cutting which could be the results of grain cutting, as well as 500 microphotos of less pronounced cutting processes and completely unused blades, it became possible to start new research of the microwear analysis (See Figure 2). 

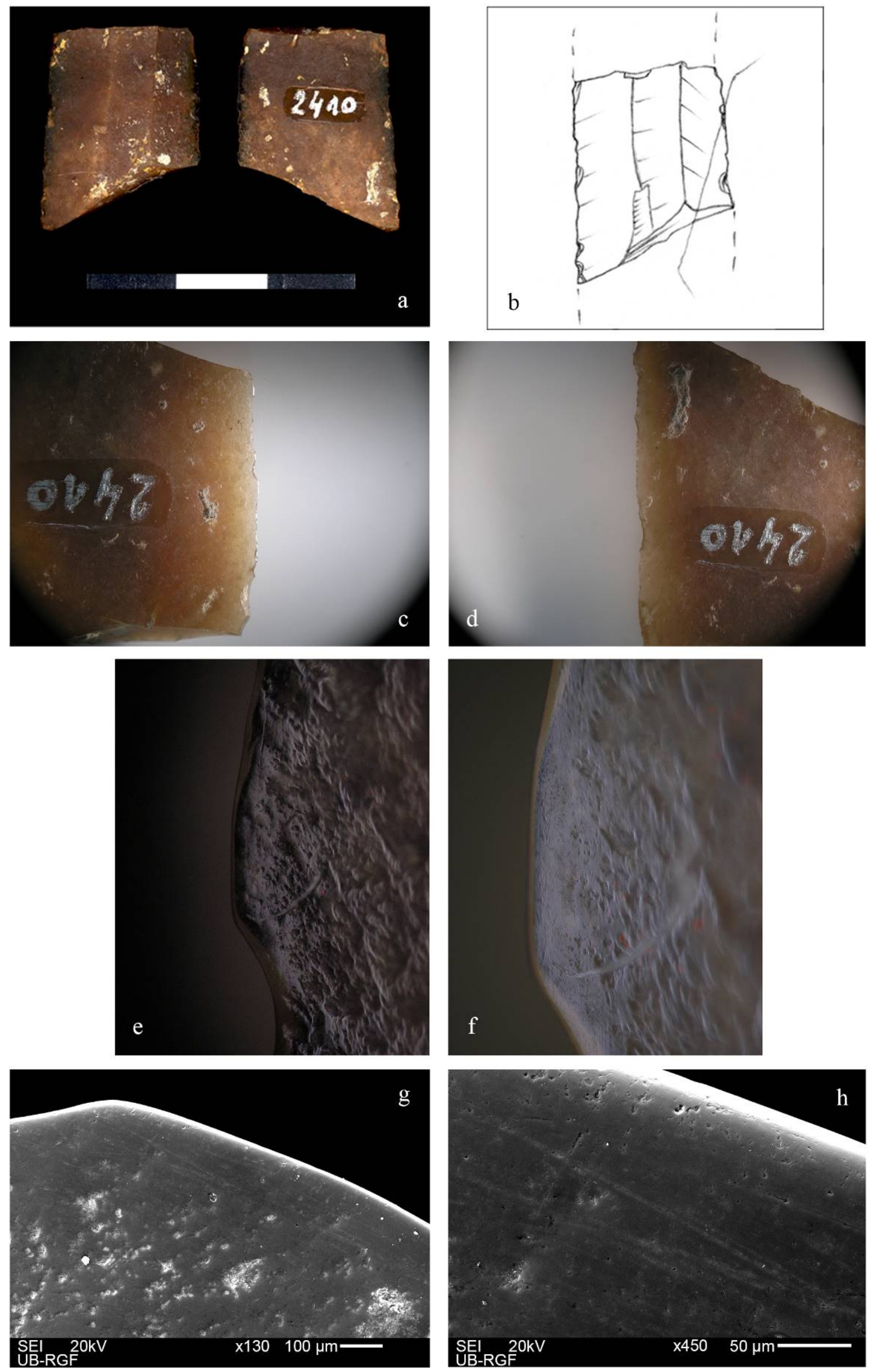

Figure 2. Vinča-Belo brdo, Vinča D horizon: a,b - sample 34; c, d - binocular (10x); e, f - metallographic microscope (70x); e - SEM (130x); f - SEM (450x). 


\section{Experiment}

The first step in the experiment was to make a sickle replica in order to compare the traces of use on the newly manufactured tools and on a large number of medial blades with the traces of shine and glossy surface registered at Vinča sites. The content of the experiment comprises two separate segments, i.e. two experiments:

- making a sickle replica; and

- growing wheat and barley cultivars on the soil of the same type in a region which is geographically close to Vinča-Belo Brdo - Experimental field "Radmilovac" (Faculty of Agriculture, University of Belgrade).

\subsection{Sickle replica}

Based on the morphology and location of sickle gloss on the blades from Belo Brdo and similar manifestations from the territory of Bulgaria and Southwest Asia, we selected a model of sickle from the site of Tell Halula, from the middle of the 8th millennium BCE (Borell \& Molist 2007: Figs. 5 \& 6). The basic tools, antler hammers and awl with metal tips were created for the needs of making the sickle, and natural stone forms were collected outside of the zone of the prehistoric mine Lojanik in West Central Serbia (Bogosavljevic Petrović 2005), see Figure 3.

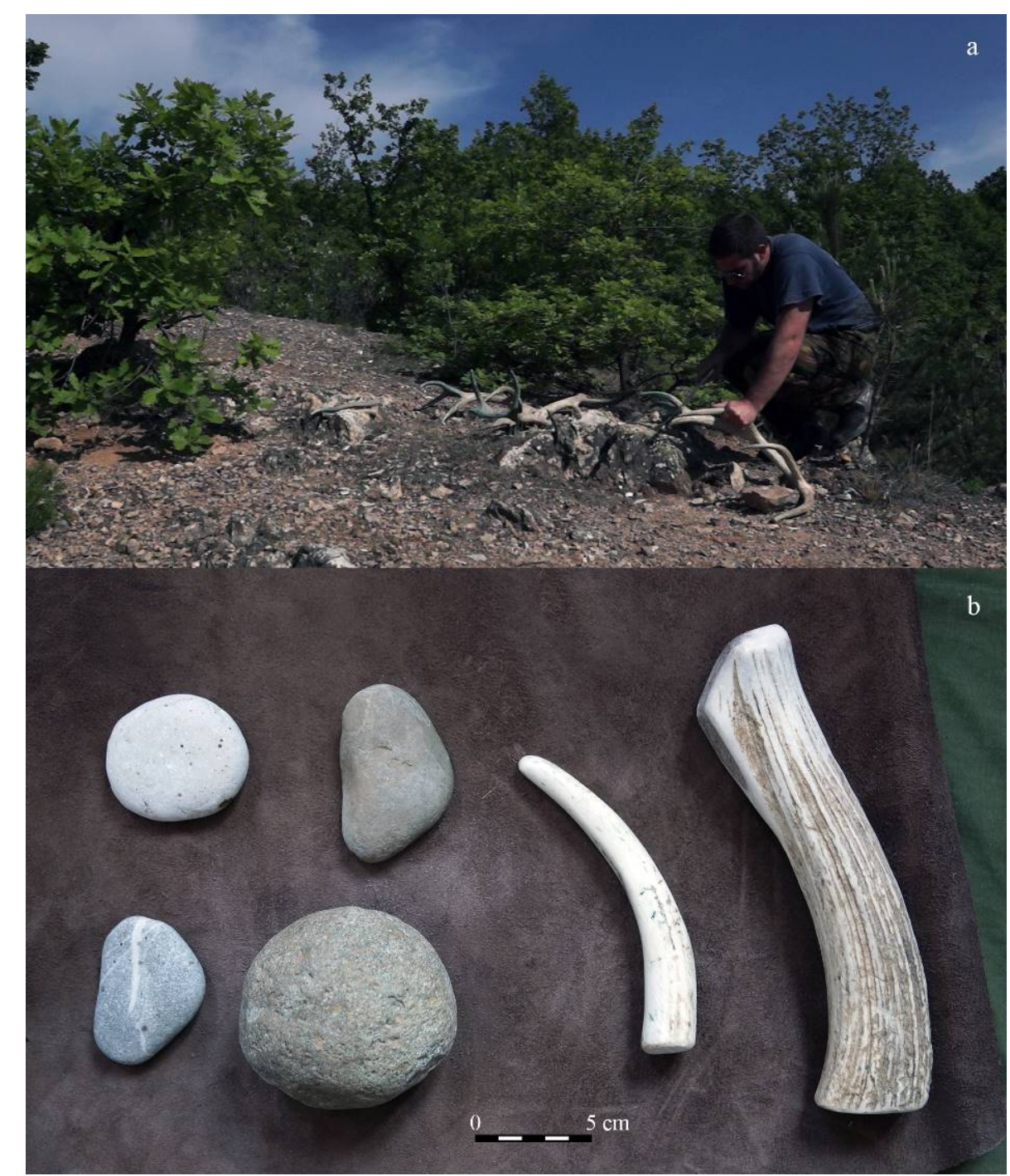

Figure 3. Fragmentation of deer antler (a) and new tool equipment for experiment (b). 
The antlers from the previous season of life cycle of deer served for making hafts, mallets and hammers and other ancillary forms of specific tools. Fragmentation of deer antlers (Figure 4a), cutting into suitable parts (Figure $4 \mathrm{~b} \& 4 \mathrm{c}$ ), the process of treatment of the surface of the tines and fork, with the application of various types of abraders (metal file, sandpaper and traditional treatment of the antler surface using a stone surface which gave the final appearance to these artefacts, Figure $4 d$ \& 4e) are part of a newly gained experience and a possibility of correlating archaeological categories, such as preparation of artefacts and artefact in function (Andrefsky 2008; Andrefsky 2009), see Figure 4.
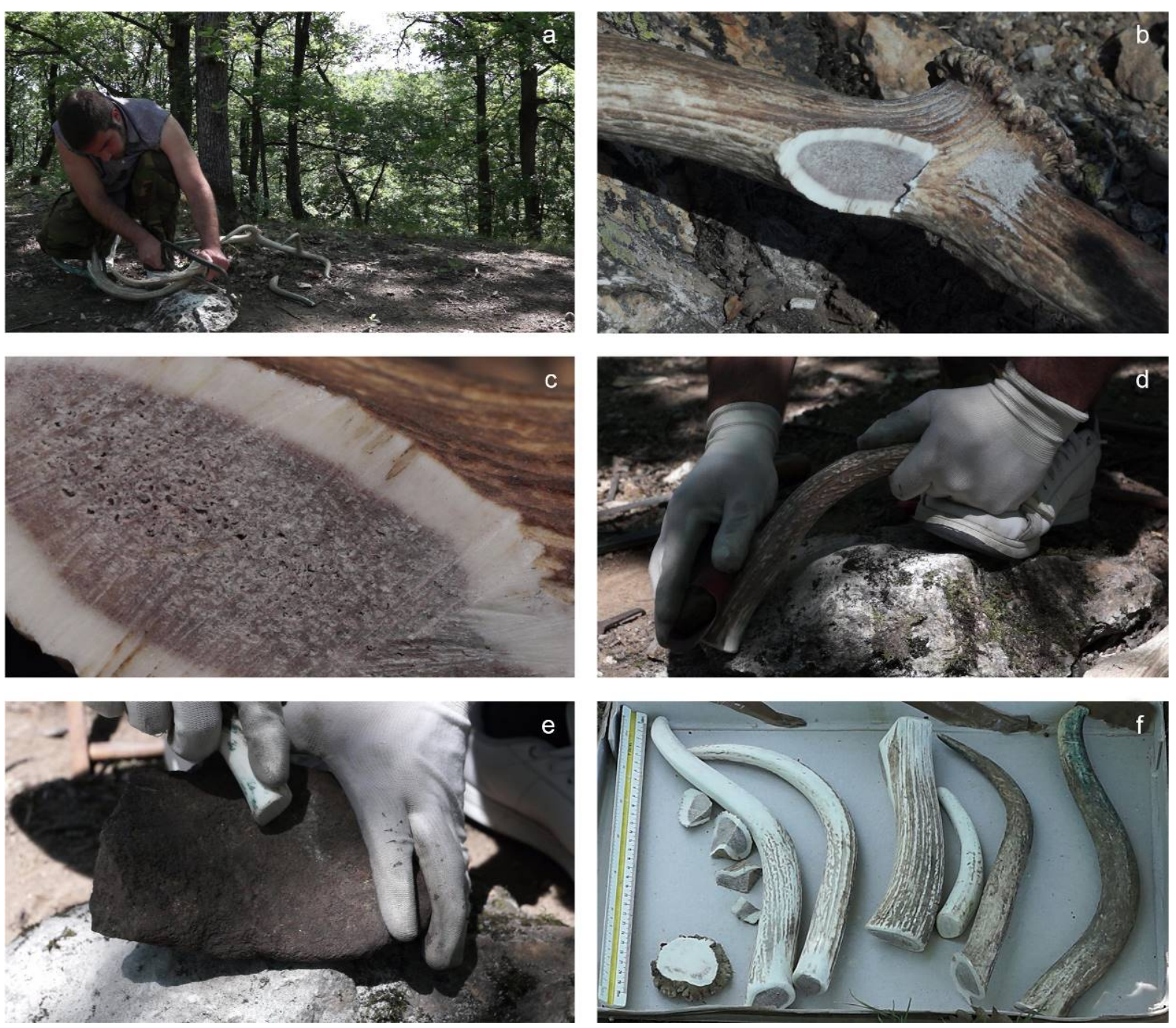

Figure 4. Basic phases of processing bone tools and products of fragmentation.

The raw materials from Lojanik, opals, cherts and other siliceous rocks, silicified wood, as well as chert gravels and chunks from the streams that gravitate to the site Vinča - Belo Brdo, were tested for blade inserts which were to be placed in the groove of the haft. A raw material from the secondary deposit in a stream near Belgrade was selected. According to its macroscopic characteristics, it is similar to the main raw material used in the Late Neolithic settlement Vinča D, in households dated ca 4500 (Tasić et al. 2015). It is brown and light brown amorphous chert, the preferential raw material in the latest horizon of the settlement Vinča-Belo Brdo with $47 \%$ of use if compared to other raw materials (Bogosavljević Petrović 2015: 268, Tab. 25), see Figure 5. 

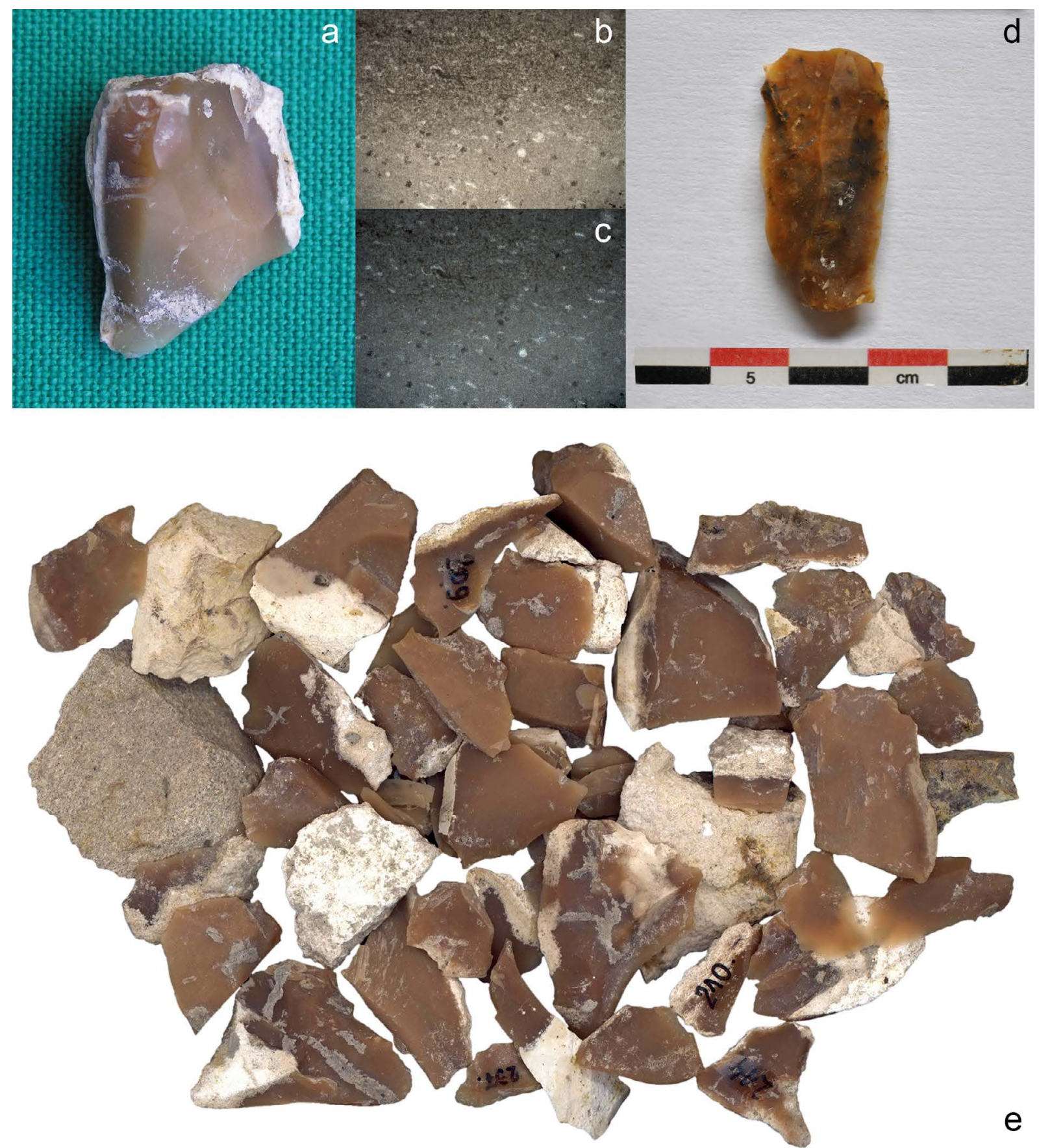

Figure 5. Vinča-Belo Brdo: a, e - light brown and brown chert with remains of radiolarians; b, c - thin-section photomicrographs of sample 1513 (25x) (after Cvetković \& Šarić 2008); d - new acquisition of similar chert for sickle replicas.

The third phase in the experiment of making the sickle replicas (two specimens) was formation of a groove by precision grinding machine (width: 2-4 mm, depth: 2-4 mm) in the curved part of the antler for the purpose of applying the newly made insert blades, and the fourth phase was inserting bladelike pieces in the groove of the antler haft. Preparation of the binder in the open fire conditions, pine resin with coal (4:1) without control of heat, which was far higher than necessary, influenced the final outcome. On that occasion, the binder poured into the sickle prototype solidified quickly and transformed into a brittle glass-like mass (Figure 6b). The second attempt was fruitful under controlled laboratory conditions. By heating the haft to $60^{\circ} \mathrm{C}$ during an hour, the potting resin to $150^{\circ} \mathrm{C}$, warming blade inserts 
produced good results, the teeth were slowly connected to the cut groove, which was the intention of the experimenter (Figure 6c and 6d).

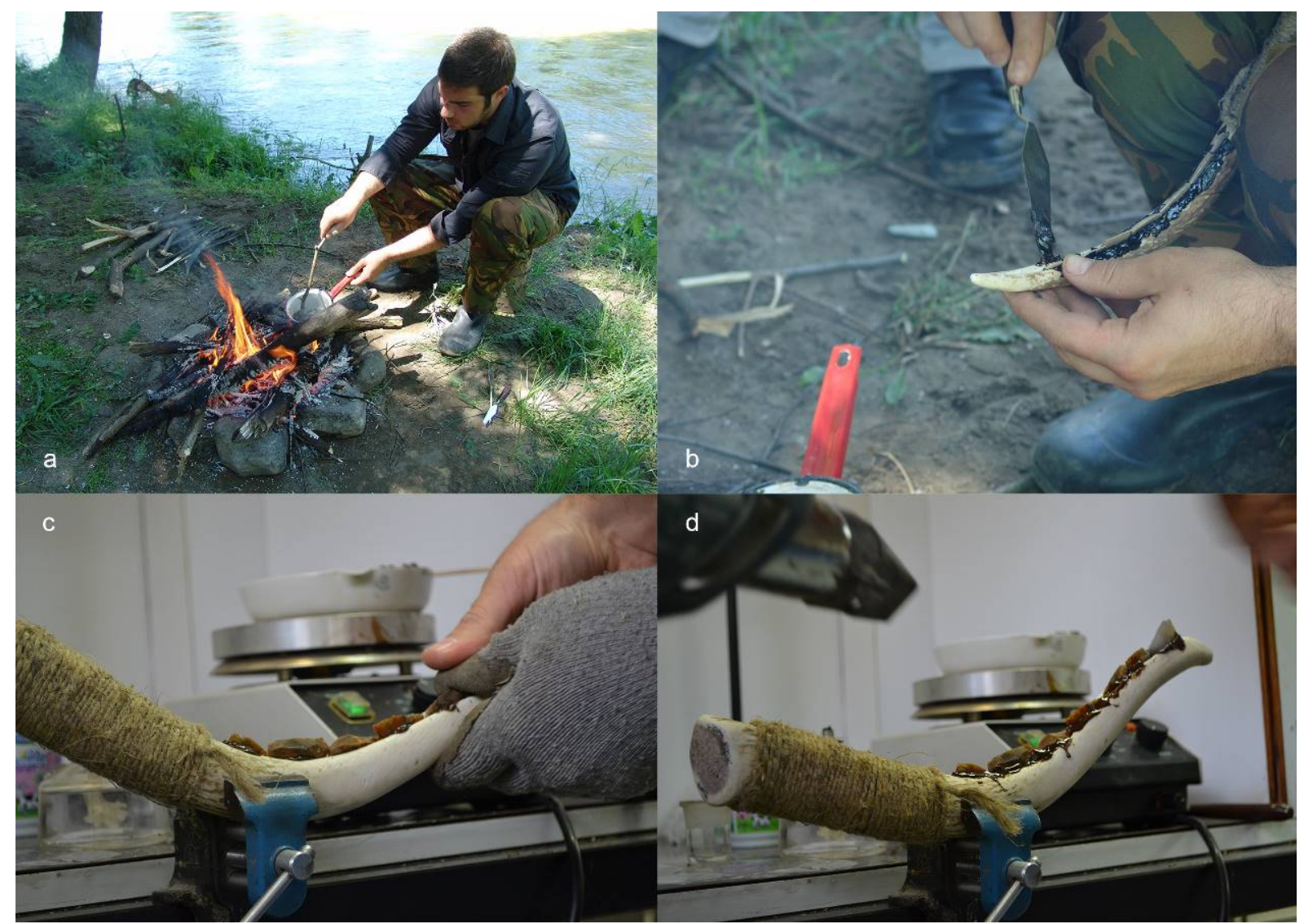

Figure 6. a, b: inserting in the open fire condition; c, d: inserting in controlled laboratory condition.

\subsection{Grain}

Sowing and soil preparation were done according to the advice of experts on the soil where there has been no sowing in the past two decades, on a soil base which is similar to the surroundings of the Vinča-Belo Brdo site: chernozem, degraded chernozem, cambisol and deluvial soil (Antonović et al. 1978: 36-74). Old cultivars of wheat with their specific characteristics were sown: Bambi (T. aestivum var compactum), Banatka (T. aestivum), Bankut (T. aestivum), Nirvana (Triticum spelta), Barley NS-565 (Hordeum vulgare var distichum) and Triticum monococcum.

The sowing area was $56 \mathrm{~m}^{2}$ (Figure 7a-d). With systematic monitoring of vegetation, recording of changes, with expert's advice, separation of areas with and without weeding, the harvest was carried out during June 2013. During the harvest, the cutting speed was measured by sheaves, i.e. the approximate number of stalks in a sheaf for the purpose of calculating possible dynamics of harvesting on a larger area (Figure 7e-h). Stalks were cut 10-15 cm on average above the ground, which was the custom in central Serbia until five decades ago (Figure 7e and 7f). In the next two years (2014 and 2015), the use of sickle 1 increased to nine hours, and sickle 2 to three hours of active operation. 

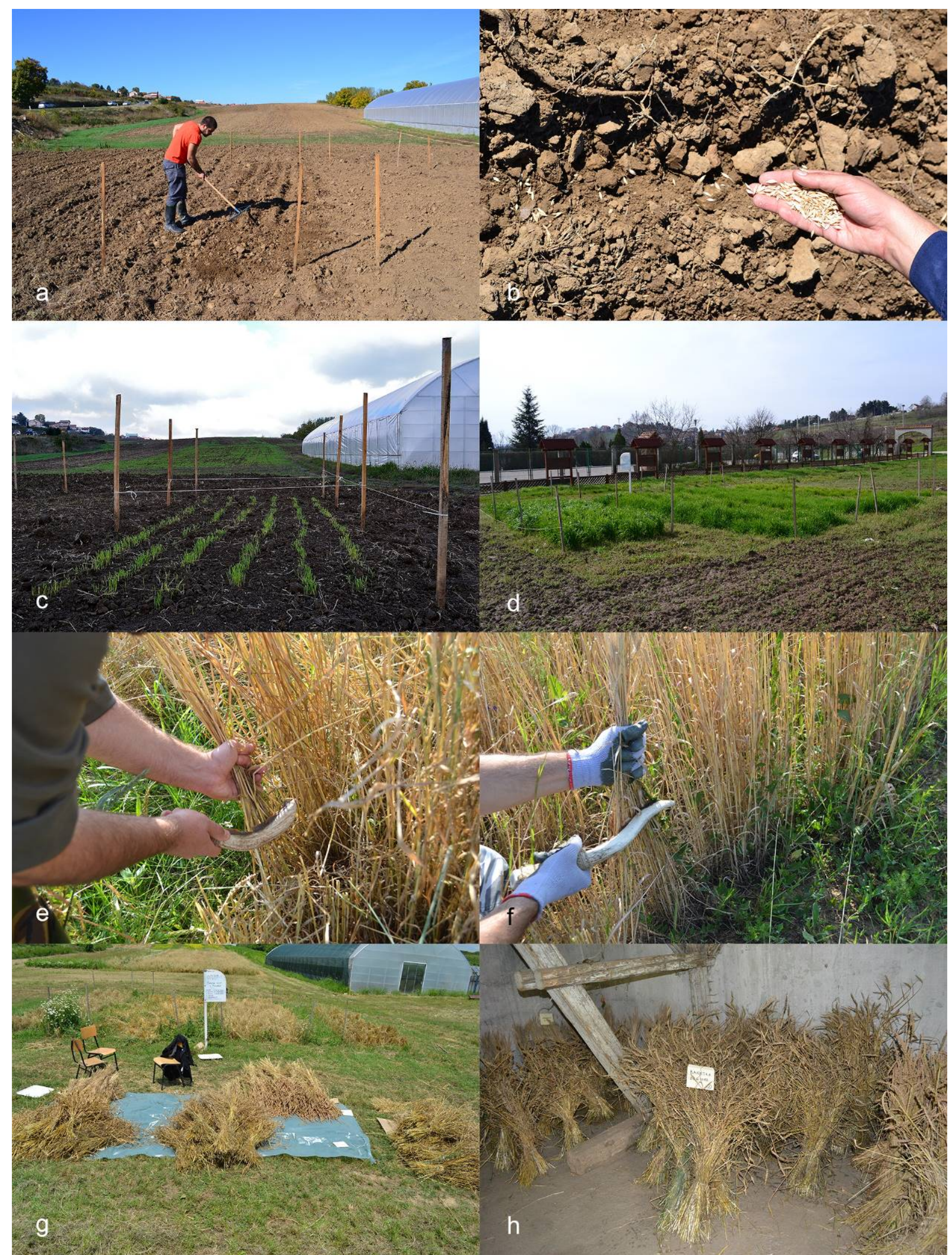

Figure 7. Sowing, harvest and storage of cereals before threshing: 28 June, 2013.

\section{Preliminary results of the experiment}

A large number of operations were implied in making a replica and its use: from the selection of stone raw materials, ground and seeds cultivation of cereals with monitoring to manufacturing of sickle replicas. Making a replica implied the acquisition of deer antlers, 
fragmentation and treatment and flaking of stone raw materials. Training the experimenters for the purpose of creating routine resulted in making sickle inserts and the finalization of replicas. What followed was microscopic examination before harvesting, storage, threshing and microscopic examination after harvesting. Both sickles are well-made replicas taking into account the fact that during the cutting operation neither difficult circumstances in the execution of the working operation nor possible defects were noticed.

Our preparation of sickle replicas significantly influenced the understanding of archaeological artefacts, byproducts and antler waste as well as the estimation of time necessary for treatment. The search for stone raw materials, which are, by their quality, related to those from Vinča, turned out to be a more difficult part of our job regardless of the knowledge of the geological situation in the field and the already noticed geological deposits suitable for treatment.

The new experiences about the quality of knapping by means of hammerstones and hard percussion (Figure 8a) and antler billets on different types of raw materials were gained (Figure 8b, 8c, and 8f). Far more regular flakes were made by antler billets (Figure 8b and 8f). The simulation of knapping technique contributed not only to the self-confidence of the knapper and creation of the necessary minimum experience, but it also allowed us to monitor the following phenomena:

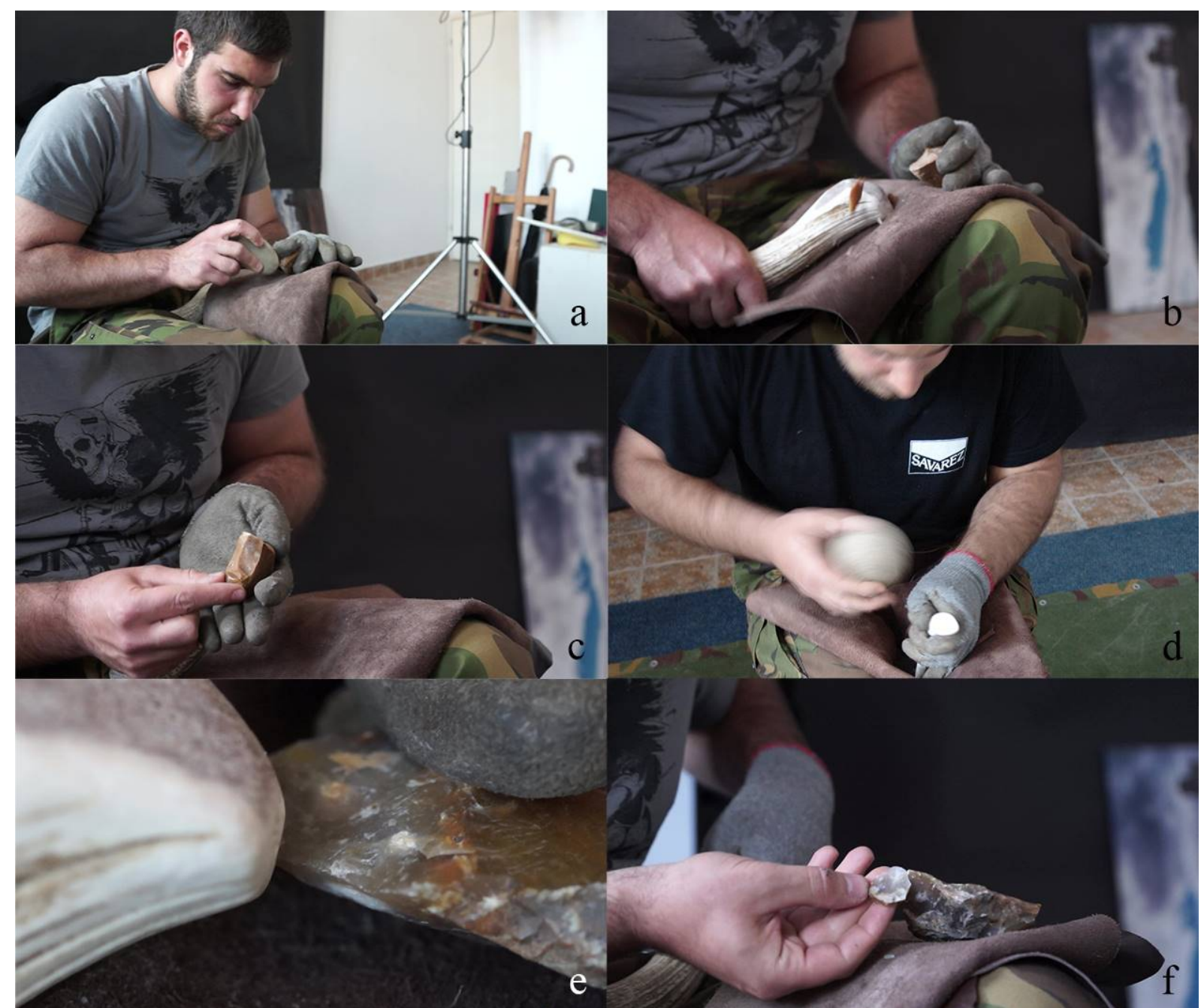

Figure 8. Exercises: hard hammer percussion and soft-hammer percussion as a corrective in future analysis of chipped stone assemblages. 
Primary flakes obtained by hard percussion are very sharp (Figure 9b-c). The impression is that the raw material is not most suitable for the whole knapping operation. Microcracks in the middle of the material are the reason for rejection (Figure 9f). Each exercise lasted approximately 10-15 minutes on cores with the average lengths of 7-8-10 cm, thickness and width 4-5-7 cm, weight $250 \mathrm{~g}$ on average. For example, Exercise 2 is one of the good examples of obtaining data about the main phases of production, the main categories of artefacts, as well as quantified data for typical raw materials of the late Vinča culture: raw materials with the weight of 240 g (Figure 9a), massive flakes - 40 g (Figure 9b), blanks - 35 flakes and blades ( ca $118.50 \mathrm{~g}$ ), blank for endscraper - $16 \mathrm{~g}$ (Figure 9d), waste - $36 \mathrm{~g}$ (Figure 9e), microblades - 5.88 g (average per single: 0.19 g) Figure 9c, exhausted core with microfractures - $59.5 \mathrm{~g}$ (Figure 9f).

The comparative monitoring of the process of flaking from the core in the experiment and vice versa, through the archaeological record from the Lojanik mine, was of great use for studying technological specificities through time on the same raw material (see Figure 10). It was noticed that the preparation of tabular raw material for core on silicified wood lasted for an incomparably shorter period and that good results were obtained. By following the traces of actions by an antler billet on the platform of the newly produced core and the same categories on archaeological artefacts, indisputable visual corresponding traces which define this type of percussion on raw materials of similar quality were confirmed (Figure 10c and 10f).

Laboratory preparation of pine resin in the proportion with coal is a specially gained experience that resulted from the insufficiently studied situation in the open air (see Figure 6). Fixing medial blades was the most sensitive part of the task of making a sickle. The lack of our own experience as well as a modest fund of scarcely published data made us perform simulations of several options and circumstances. It influenced more intensive studying of preserved residues on the surface of archaeological blades in order to define the original binder. The selection of pine resin with the proportion of coal is the result of collected data from oral tradition of the local population.

We controlled the performance of the process of grains in order to record the necessary data, so that the number of stalks was measured per armful per $1 \mathrm{~m}^{2}$. On the area of 1 square metre in 10 minutes of the activity, the reaper cut 42 armfuls using approximately 210 movements. It is about 1300 stalks. In 1 hour and 30 minutes there were approximately 2100 and 2200 cutting movements on 16 square metres. According to these data, on the area of one hundred square metres a modern reaper could make about 19,000 (without experience) to 14,000 (with experience) movements using a sickle, which is a good indicator for calculation of the length and duration of insert pieces in the sickle. The time necessary for harvesting one hundred square metres ranges between six and seven hours of active cutting using a sickle according to the stated experiences, i.e. it is reduced to one day if preparatory activities, rest, arrangement of sheaves, conversations, weather conditions, etc. are taken into account.

In the harvest of 2014, sickle 1 operated for additional four hours, making the total of seven hours. In that period, the reaper managed to reap the area of one hundred square metres without any significant problems. No damages on the sickle were noticed, such as inserts defects. In the middle zone, there were macroscopic traces of very modest traces of micropolish, which was not the case with the scope of three hours of active cutting.

The main location of cutting by using sickle 1 was in the middle and lower medial zones, on teeth marked as IV, V and VI from the sickle tip (Figure 11a). The resistance was registered on teeth IV toward V (magnification of 10 and 30 times at distal and ventral sides on Figure 11). The most important result achieved is noticing the initial process of deformation of the original blade edges after three hours of active work. Magnifications of 50 and 60 times were enough to obtain early signs of deformation of the edge. Burrs, formation 
of round parts and initial forms of polishing on the raw material which is of medium quality, with insufficiently perfect tearing, not extremely bad to allow its petrographic composition with admixtures to considerably influence the foreseen intention are the indicators of the three-hour activity. Macroscopic shine was not noticed in this phase. The micropolish with a smooth surface was formed between the third and seventh hours of active operation of the sickle (Figure 11e). After seven working hours, “our” shine could be seen with the naked eye. The conclusion is that after the area of about 150 square metres of grain cutting, micropolish starts to form and in further exploitation it should develop into a typical sickle gloss.
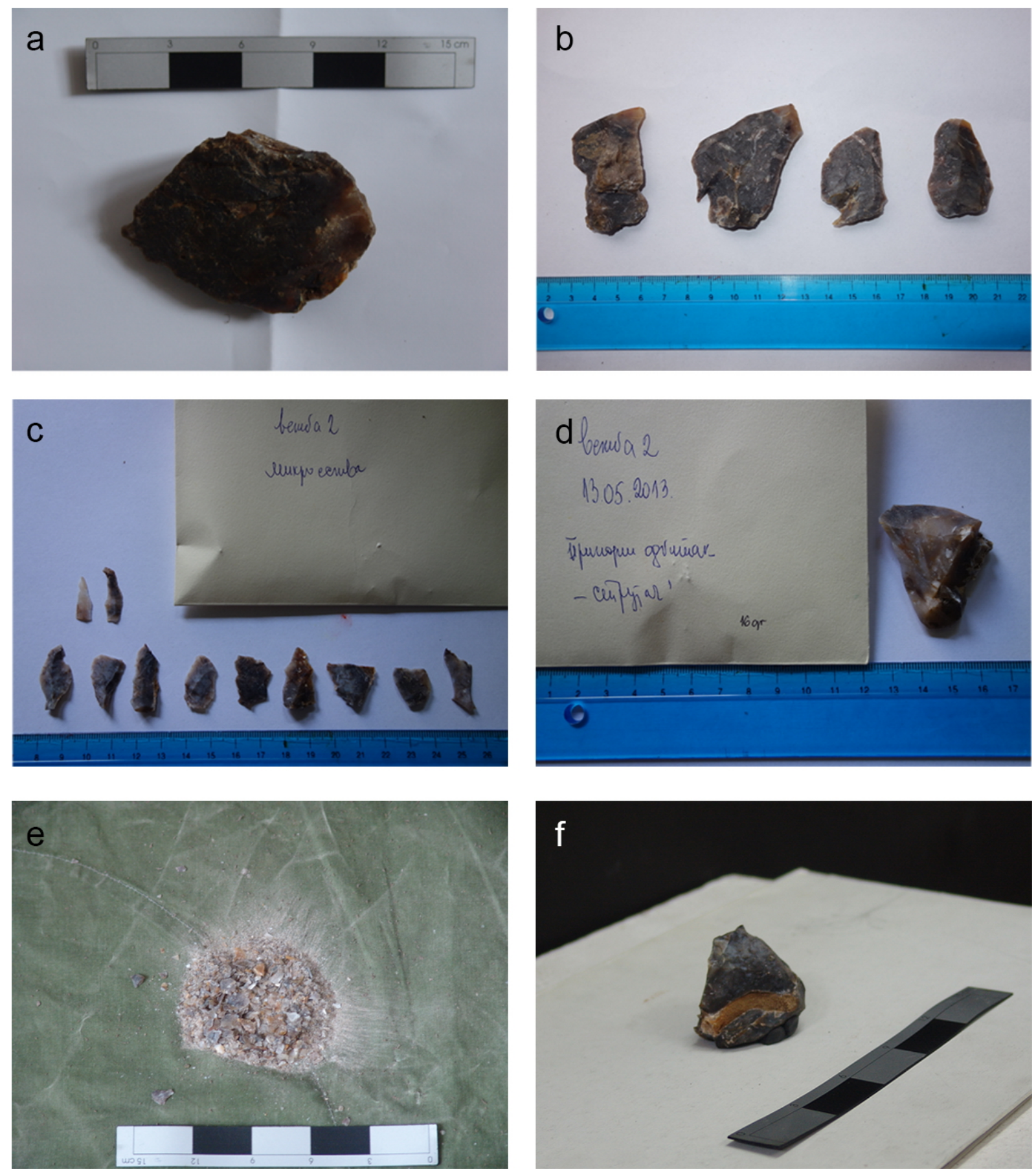

Figure 9. Basic phases in core exploitation with products of flaking. 

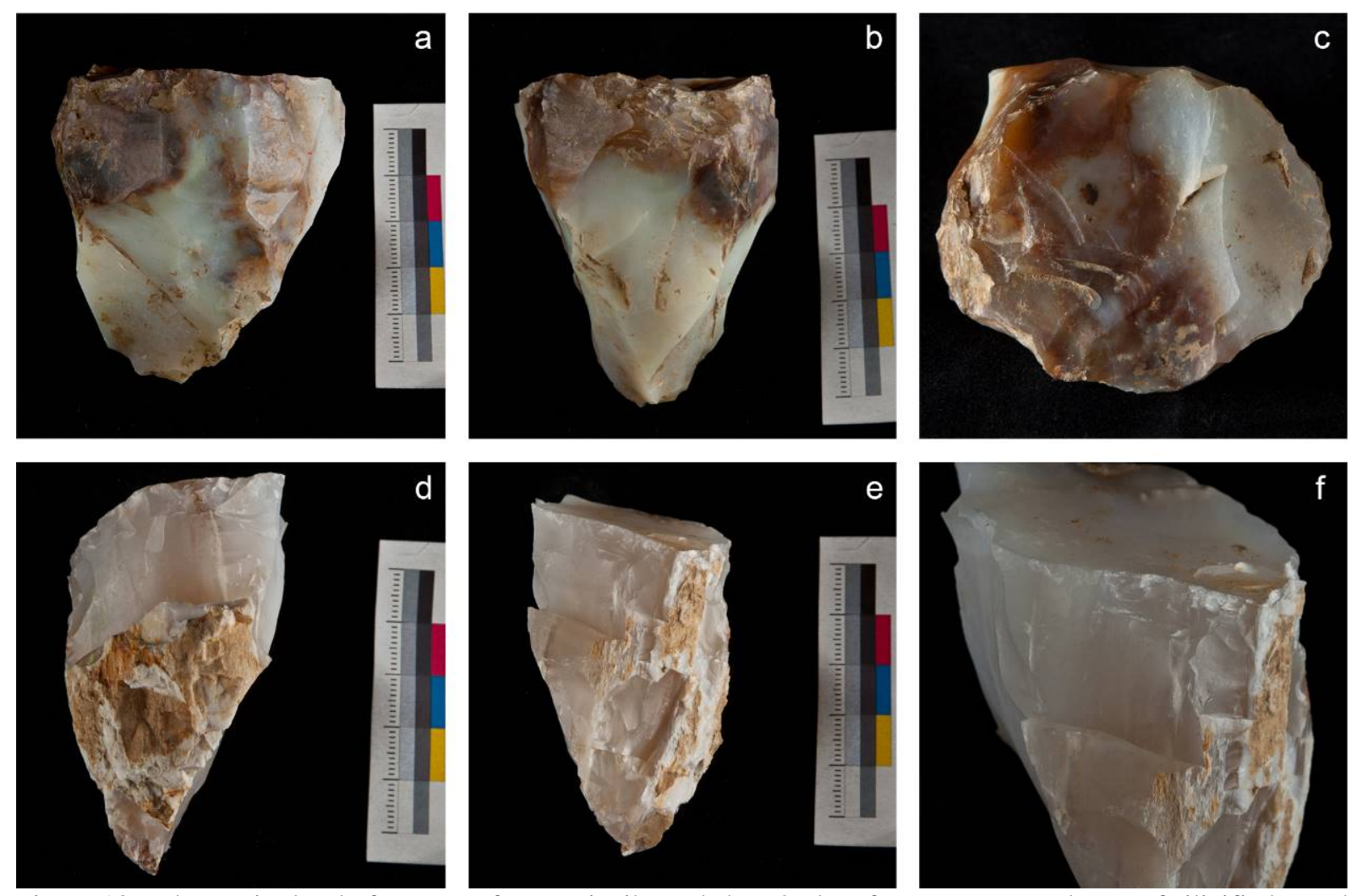

Figure 10. a, b, c - single-platform core from Lojanik workshop 2; d, e, f - new processed core of silicified wood from Lojanik hill (May, 2013).

\section{Discussion and conclusions}

By devising a sequence of procedures, we entered the system of modern lithic organization, as it is defined by William Andrefsky, which was the greatest result in our approach (Andrefsky 2009). It turned out that the realization of the experiment implied a far wider framework of preparation and observation, thus coming closer to the poorly visible boundary between objective state and subjective estimate, an eternal dilemma and the moving question in archaeology.

A significant advantage of this experiment, among others, was the possibility of comparing different phases of reduction processes of archaeological examples and examples from the experiment. The questions that were of our special interest were those of the strategy of providing raw materials and the technological processes of knapping with characteristic traces. The final goal of obtaining blades which were subjected to the actions of cutting grains for the purpose of creating a reference collection is still being realized, but with the possibility of monitoring how damages from use are formed from season to season.

Average weights of pre-cores between 260-280 grams were compared with archaeological samples. Why the pre-cores of that weight? The weight of the largest number of preserved cores from the initial phase of exploitation from the Vinča sites in Serbia is up to 300 gr. It determined the first measurements and created the basis for investigating quantification of needs of a community at the level of season. For the settlements which were outside suitable geographic zones rich in siliceous rocks, such as Opovo and Gomolava from the southwestern part of the Pannonian plain, the question of strategy of providing raw materials became more transparent on the basis of the following preliminary observations (see Figure 1). 
a
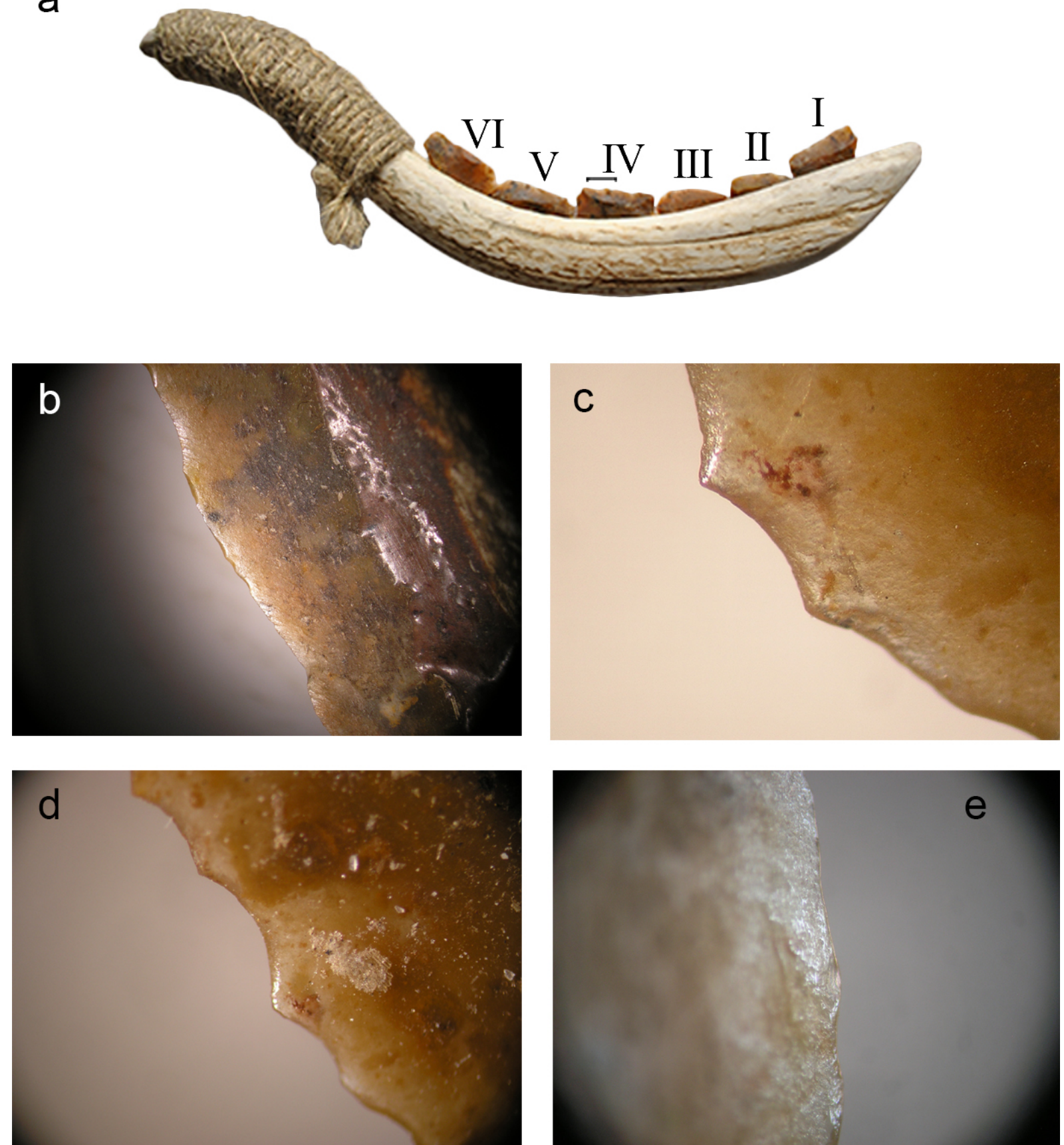

Figure 11. Vinča-Belo Brdo. a - replica 1; b - part of edge IV before harvest, c - after three hours of use (60x); d - after seven hours (30x); e - after nine hours (60x).

Measuring weights of archaeological samples of three blades from the Late Vinča-Belo Brdo site, made of different raw materials, (ochre amorphous chert, ochre radiolarite chert, and ochre radiolarite, the length from 47 to $60 \mathrm{~mm}$, the weight from 3.27 to 5.19 and $5.88 \mathrm{~g}$ ) contributed to noticing possibilities of calculation of the number and weight of, before all, preserved cores (Figure 12a-c). The calculations which followed showed that it is possible, after partial decortification of the globular core from Grivac site weighing $1475 \mathrm{~g}$, to obtain over 125 blades with parallel edges which are ca $80 \mathrm{~mm}$ long and ca 60 flakes (Bogosavljević Petrović 2008: 372-373), Figure 12d. From one blade of that length it is possible to obtain three fragments resembling insert blades. For completing the sickle of our replica type, it is necessary to prepare a couple of blades that will be successfully fragmented into two or more 
suitable parts and keep the remaining blade inserts in the tool kit of reapers. Thus, the needs for raw materials in the period studied here become more transparent.
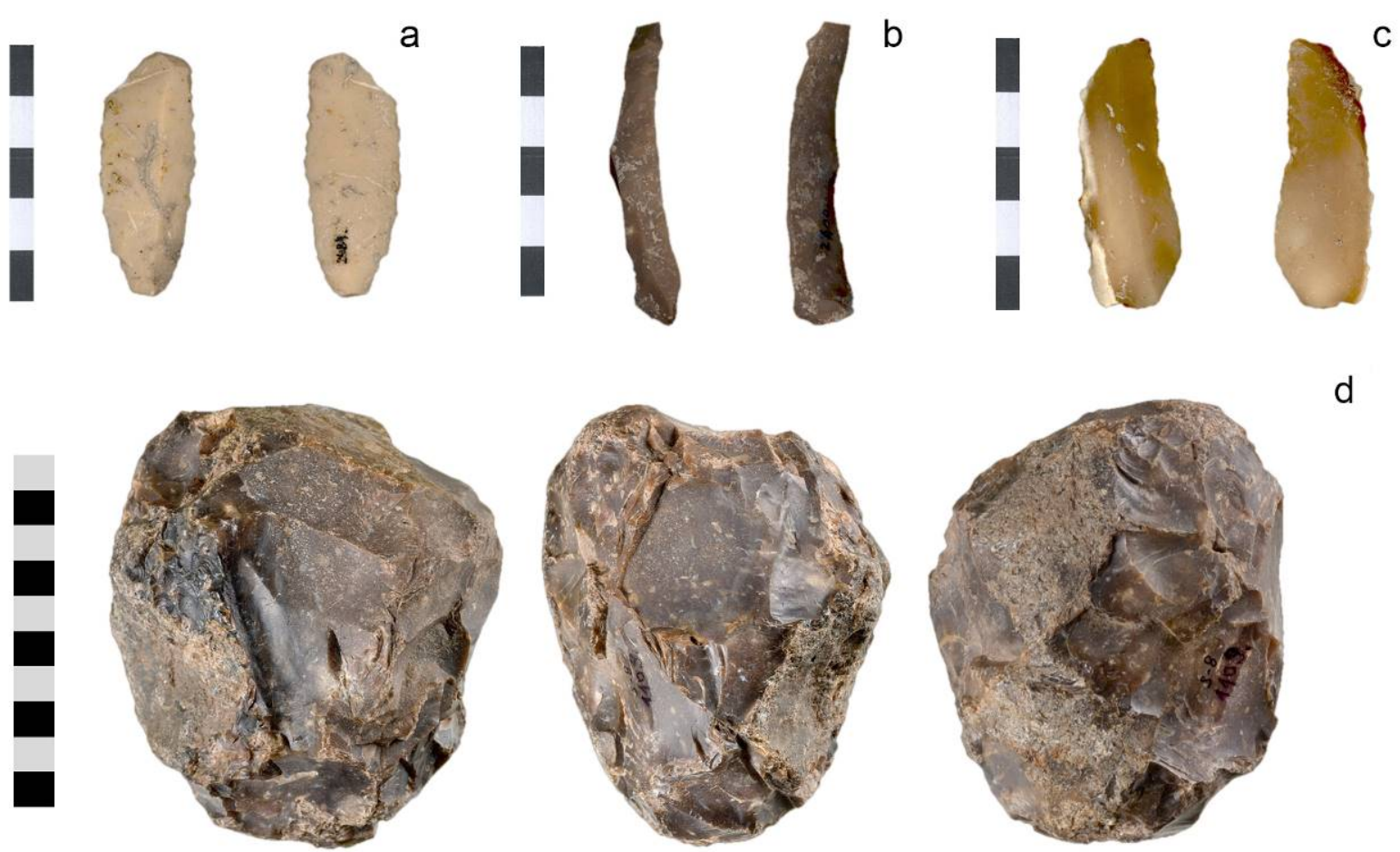

d

Figure 12. Blades from Vinča - Belo Brdo: a - ochre amorphous chert, b - ochre radiolarite chert, c - ochre radiolarite, d - globular core from Grivac. (Scale bar segments are $1 \mathrm{~cm}$ each.)

There is an impression that a dozen of cores which are hand-sized, or several more massive ones, represent a quite acceptable burden in the "rucksack" of a supplier from Vinča during transportation to the working camp or settlement. At the theoretical level, it was possible to use that quantity for making specific purpose tools such as the number of sickles necessary for harvesting during one season on the basis of data from the investigated Vinča settlements.

Making blades which were suitable for inserting in the sickle made us collect a large number of technological information that may be available in an archaeological collection. As a rule, they were interpreted based on analogies from remote regions and from a different period of time. This time we mastered the practices of direct and indirect percussions by hammerstones and antler billets on local raw materials of different quality and obtained the traces generally left by applying such techniques. All data are comparable with adequate artefacts from the archaeological collections for the period of the Vinča culture (see Figure 10).

Making microcores of tabular raw materials was widely present as production in the Late Neolithic in Serbia (Gunn 1988: 228-229; Voytek 1990: 446; Bogosavljević Petrović 2015: 489-490). Such cores were interpreted as a result of easy availability of raw materials of small dimensions, the possibility of fast preparation and exploitation without a lot of energy invested, but also as a result of "exhaustion" during exploitation. On the example of opal raw materials (silicified wood from Lojanik), exercises in the experiment convincingly affirmed the standpoint of small consumption of energy when tabular raw materials are in question; this refers to several flakes removed and obtaining suitable surfaces for exploitation. Five minutes passed from the first blow to the advanced blade production, which indicates a far faster rhythm when technological practices are empirically well adopted and when the quality of raw materials is known. 
Traces of soft hammering on the cores from the experiment are identical to the archaeological specimens, which demonstrates the criterion for classification into technological categories for soft hammering. In that case, antler billets and soft hammering technique with punch technique prevails in late horizons of the Vinča culture settlements. Before the experiment, it was possible to roughly determine the technological processes, but there were no adequate visual data which could be checked.

Every exercise in knapping raw materials served for recognition of the main categories in the production of cores as well as of their quantitative parameters. For the researchers of always rich Vinča assemblages of chipped stone, the categories such as waste and blanks thus became initially "visible" and comparable to the original specimens. The process of fragmentation of antlers represents data for recognition of the main categories in bone industry of the Neolithic period in Serbia. The comparative assemblage for both industries, i.e. chipped stone industry and bone industry, has been the thing lacking in current research from this territory in the last two decades.

Quantification of the needs for production of grains was a new thesis and a completely unknown field of work until the realization of this experiment. We accepted the suggestions that eight members made the basis of a larger family from a household of a larger area, or six members at the most general level of observation within the Vinča culture (Porčić 2011; Porčić 2012). From the area of 56 square metres, $16.5 \mathrm{~kg}$ of grain and $23 \mathrm{~kg}$ of straw were obtained. According to the calculation, the quantity of grain sufficient for a family of five members for a week was produced, under condition that this group could consume between one and two kilograms of grain daily. If our crop for a year is calculated, it is necessary to sow about 3000 square metres at the annual level, under ideal weather conditions, such as during the vegetation of 2012 and 2013.

Calculations of the number of movements made for the mentioned working time and the quality of the accompanying shine are directly connected with the quality of raw material, the type of grain and the degree of the humidity. For us, the important fact is that a properly created sickle can be a tool which could last for more than one season. Similar experiences were obtained for the period of the early Neolithic in Southwest Asia in observation of tool life-history by developing a method to quantitatively estimate harvesting intensity (Goodale et al. 2010: 1199).

Measuring the area and the time consumed also quantifies the number of involved members of the community, which opens the perspectives of studying at the level of household and settlement. If a person can reap an area of one hundred square metres per day (tolerant framework because of the subjective feeling of our "reapers" that they can work more and faster), then some ten members of the community could reap 3000 square metres of their fields in two days. In relation to the data from Belo Brdo from the latest phase (Vinča D), which revealed houses with several rooms and a complex form of organization (Tasic et al. 2015: 1067-1071, Figs. 5 \& 7), a research study of the scope of those activities could be initiated, taking into consideration a lot of parameters, one of them being very important - the quantity of rejected blades with the traces of shine resulting from cutting grains.

The elaboration of the task to make a sickle replica initiated more than one question posed in the first part of this paper. The process of making a sickle, the sowing process, harvesting and threshing are complex activities which mobilize a large number of people. Our experiments introduced the first quantified data for the following phenomena:

- creating the replica for studying of use-wear;

- complexity of new lithic organization and estimation for every stage of the experiment;

- observation of the time needed to form the first deformations (micropolish);

- first quantitative records about the needs for cereals per hypothetical Vinča family; and 
- first precise indication about human land-use in the surroundings of the Vinča site during the Late Vinča culture.

The main implication of the archaeological experiment is starting the question of complexity of the Vinča society, the question of inequalities from the angle of more concrete data about the needs of a smaller group of people relative to organized larger structures. Quantification of time, people, tools and grains is undoubtedly a far more concrete context for establishing the main parameters in the analysis of social ranking (Porčić 2012).

The problem is far more complex than the above-mentioned formulation. Other cutting processes which are closely connected with grains, before all cutting weeds, should also be considered. Development of the concept of sowing, harvesting and threshing brought us, due to following traces of use on the replicas, to the extension of the scope of experiment. The projections of a possible number of members of the community, as well as of a potential area of land that used to be exploited in the surroundings of Vinča-Belo Brdo site are thus the first concrete data about this issue within the Vinča culture. In our opinion, the beginning of experimental following of traces of use and simulation of working operations on knapped tools represents the necessary comparative context for interpretation of human activities in Late Neolithic and Chalcolithic of the Central Balkans.

\section{Acknowledgements}

I am deeply grateful to my associates Jelena Marković, Vidan Dimić, Ksenija Borojević, Jovan Mitrović, Aleksandar Bandović, Milica Stojanović, Slobodan Tripković, Srdjan Vulović, Jelena Ćeriman, Djordje Radonjić, Biljana Djordjević, Mija Ranković, Stevan Djuričić, Dragan Janković, as well as to a team of experts from Radmilovac. The experiment is the result of work on the project of the National Museum in Belgrade "Origin, Interpretation and Distribution of Stone Raw Materials in the Prehistory of Serbia" (V. Bogosavljević Petrović, project director).

\section{References}

Andrefsky, W. Jr. 2008, An introduction to stone tool life history and technological organization. In: Lithic technology - Measure of Production, Use and Curation (Andrefsky, W. Jr., Ed.), Cambridge University Press, Cambridge: p. 1-22. doi:10.1017/CBO9780511499661.002

Andrefsky, W. Jr. 2009, The Analysis of Stone Procurement, Production and Maintenance. Journal of Archaeological Research, 17: 65-103. doi: 10.1007/s10814-008-9026-2

Antonović, G., Živanović, Bogdanović, M., Ćorović, R. \& Trifunović M. 1978. Zemljišta, područja Beograda južno od Save i Dunava. City Geodetic Authority, Belgrade, 438 p. (in Serbian) ("Soils of the Belgrade area south of the Sava and the Danube").

Antonović, D. \& Šarić, J. 2011, Kameno orudje sa lokaliteta Crkvine u Stublinama, Starinar, 61: 61-79. (in Serbian) ("Stone tools from localty Crkvine in Stubline”). doi:10.2298/STA1161061A

Bogosavljević Petrović, V. 2001, New Results of the Study of Chipped Stone Industry of the Vinča Culture, Viminacium, 12: 35-50.

Bogosavljević Petrović, V. 2005, Praistorijski rudnici na centralnom Balkanu. Zbornik narodnog muzeja u Beogradu. Recueil du Musée National à Belgrade, 18(1): 79-113. (in Serbian) ("Prehistoric Mines in the Central Balkans").

URL: http://www.narodnimuzej.rs/images/ZBORNIKXVIII-1arheologija.pdf 
Bogosavljević Petrović, V. 2008, Flaked Stone industry. In: Grivac Settlements of ProtoStarčevo and Vinča culture (Bogdanović, M., Ed.), Center for Scientific Research of Serbian Academy of Sciences and Arts and University of Kragujevac and National Museum of Kragujevac, Kragujevac: p. 355-409.

Bogosavljević Petrović, V. 2011, Redukcija kamenih sirovina na lokalitetu Crkvine - sonda 5 sa arheološkim celinama. Kolubara, 5: 213-238. (In Serbian) ("Lithic reduction at the site of Crkvine - trench 5 with archaeological wholes").

Bogosavljević Petrović, V. 2015, Razvoj industrije okresanog kamena u vinčanskoj kulturi na teritoriji Srbije. Doctoral dissertation no 306 at the Faculty of Philosophy, University of Belgrade, Belgrade, 547 p. (in Serbian) ("Evolution of the chipped stone industry in the Vinča culture in the territory of Serbia”).

Bogosavljević Petrović, V., \& Marković, J. 2012, History and current studies of petroarcheological data from the Neolithic and Eneolithic in Serbia. Bulgarian eJournal of Archaeology, 2(1): 51-66. URL: http://be-ja.org/wpcontent/uploads/2012/05/Be-JA_1_2012_51-66.pdf

Borrell, F. \& Molist, M. 2007, Projectile Points, Sickle Blades and Glossed Points: Tools and Hafting System at Tell Halula (Syria) during the 8th millennium cal BC. Paléorient, 33(2): 59-77. doi:10.3406/paleo.2007.5221

Borić, D. 2009, Absolute dating of metallurgical innovations in the Vinča Culture of the Balkans. In: Metals and Societes. Studies in honour of Barbara S. Ottaway (Kienlin, T. K. \& Roberts, B. W. Eds.), Universitätsforcshungen zur prähistorischen Archäologie, Bonn: p. 191-245.

Borić, D. 2015, The end of the Vinča world: Modelling Late Neolithic to Copper Age culture change and the notion of archaeological culture. In: Neolithic and Copper Age between the Carpathians and the Aegean Sea. Chronologies and Technologies from 6th to 4th millennium BCE, International Workshop Budapest 2012 (Hansen, S., Raczky, P., Anders A., \& Reingruber, A., Eds.), Archäologie in Eurasien Vol. 31, Habelt, Bonn: p. 177-237.

Cvetković, V. \& Šarić, K. 2008. Petrografska analiza uzoraka okresanih alatki sa lokaliteta Vinča - Belo Brdo. Report. Faculty of Mining, Department of Petrology and Geochemistry, University of Belgrade. Belgrade, 33 p. (In Serbian) ("Petrographic analysis of chipped stone artefacts from the Vinča - Belo Brdo site”).

Goodale, N., Heather, O., Andrefsky, W. Jr., Kuijt, I., Finlayson, B., Bart, K. 2010, Sickle blade life-history and the transition to agriculture: An Early Neolithic case study from Southwest Asia. Journal of Archaeological Science, 37: 1192-1201. doi:10.1016/j.jas.2009.12.017

Gunn, J. 1988, Core Manufacture and Use at Divostin. In: Divostin and Neolithic of Central Serbia (McPherron, A. \& Srejović, D., Eds.), Ethnology Monograph Vol. 19, University of Pittsburgh, Department of Anthropology, Pitsburgh: p. 226-245.

Hansen, S. 2013, Innovative Metals: Copper, Gold and Silver in the Black Sea region and the Carpathian Basin During the 5th and 4th Millennium BC. In: Metal Matters; Innovative Technologies and Social Change in Prehistory and Antiquity (Burmeister, S., Hansen, S., Kunst, M., Müller-Sceeßel, N., Eds.), Verlag Marie Leidorf, Rahden: p. 137-167.

Kaczanowska, M. \& Kozłowski, J. K. 1986, Gomolava-Chipped Stone Industries of Vinča Culture. Prace Archeologiczne Vol. 39, Uniwersytet Jagielloński, Warszawa, 136 p. 
Porčić, M. 2011, An exercise in archaeological demography: Estimating the population size of Late Neolithic settlements in the Central Balkans. Documenta Praehistorica, 38: 323-332. doi:10.4312/dp.38.25

Porčić, M. 2012, Social complexity and inequality in the Late Neolithic of the Central Balkans: Reviewing the evidence. Documenta Praehistorica, 39: 167-183. doi:10.4312/dp.39.12

Rosen, S. A. 1997, Lithics After the Stone Age. A Handbook of Stone Tools from the Levant. Alatamira Press, Walnut Creek, 184 p.

Tasić N., Marić M., Penezić K., Filipović D., Borojević K., Rusell N., Reimer P., Barclay A., Bayliss A., Borić D., Gaydarska B. \&Whittle A. 2015, The end of the affair: Formal chronological moedelling for the top of the Neolithic tell of Vinča - Belo Brdo. Antiquity, 89(347): 1064-1082. doi:10.15184/aqy.2015.101

Tringham, R.E., McPherron, A., Gunn, J. \& Odell, G., 1988, The Flaked Stone Industry from Divostin and Banja. In: Divostin and Neolithic of Central Serbia (McPherron, A. \& Srejović, D., Eds.), Ethnology Monograph Vol. 19, University of Pittsburgh, Department of Anthropology, Pitsburgh: p. 203-254.

Tringham, R., Brukner, B. \& Voytek, B. 1985, The Opovo project: A Study of Socioeconomic Change in the Balkan Neolithic. Journal of Field Archaeology, 12(4): 425-444. doi:10.2307/529968

Tringham, R., Brukner B., Kaiser T., Borojević K., Bukvić Lj., Steli P., Russell N., Stevanović M. \& Voytek B. 1992, Excavations at Opovo, 1985-1987: Socioeconomic Change in the Balkan Neolithic. Journal of Field Archaeology, 19(1): 351-386. doi:10.2307/529922

Tripković, B. 2013 Domaćinstvo i zajednica. Kućne i naseobinske istorije u kasnom neolitu centralnog Balkana. Faculty of Philosophy, University of Belgrade. Belgrade, 319 p. (in Serbian) ("Houshold and community. Histories of houses and settlements in the Late Neolithic in the Central Balkans").

Šarić, J. 2014. Artefakti od okresanog kamena u starijem i srednjem neolitu na tlu Srbije. Arheološki institut. Belgrade, 299 p. (in Serbian) (“Artefacts of Early and Middle Neolithic in Serbia”).

Voytek, B. 1984, Microwear Analysis of Chipped Stone Artifacts from Vinča. In: The Chipped Stone Industry from Vinča (Excavation 1929-1934) (Srejović D. Ed.), Univerzitet u Beogradu, Filozofski fakultet, Centar za arheolška istraživanja (Series) Vol 24, University of Belgrade, Centre for Archaeological Research, Belgrade: 54-58.

Voytek, B. 1990 The Use of Stone Resources. In: Selevac: A Neolithic Village in Yugoslavia (Tringham, R., Krstić, D., Eds.), Monumenta Archaeologica Vol. 15, Los Angeles: p. 437-494. 